\title{
「X線自由電子レーザーを用いた極限状態の観察・開拓」特集号によせて
}

\author{
兒玉 了祐 \\ 大阪大学 レーザー科学研究所 ( ₹565-0871 大阪府吹田市山田丘2-6) \\ 大阪大学大学院 工学研究科 (干565-0871 大阪府吹田市山田丘2-1)
}

\section{Preface to Special Issue on Investigation and Exploration of Extreme States of Matter with XFEL}

\author{
Ryosuke KODAMA \\ Institute of Laser Engineering, Osaka University, 2-6 Yamadaoka, Suita, Osaka 565-0871 \\ Graduate School of Engineering, Osaka University, 2-1 Yamadaoka, Suita, Osaka 565-0871
}

(Received June 9, 2017)

1960年に人類は，原子・分子の世界からレーザーとい う新たな道具を創りだし，「光と物質との相互作用」に新 しい側面を開拓できるようになった，現在，このレー ザーは，最先端の量子ビーム技術を使うことでXFELと いう形でX線の領域まで広がり, 生命科学から物質材料 科学，プラズマ科学，惑星科学さらには宇宙物理学にも 関係する様々な分野に大きな影響を与えようとしてい る.

XFELの短波長性, 短パルス性, 高輝度性が, 高い空 間分解と時間分解の構造解析を高速に実現し, 蛋白質結 晶構造解析を飛躍的に発展させる可能性がある。例え ば, 生命の存在様式とも言われている蛋白質は, 生体内 の効率的かつ効果的な生命現象の中心的役割を果たして いる。 この蛋白質結晶の構造解析は，この働きの仕組み を理解するために不可欠な研究である。このような機能 解析等を通した生命現象の統合的理解に加え立体構造に 基づく医薬の分子設計の進展等により, 医療, 産業等へ の貢献も期待されている. また, コヒーレントなXFEL を利用したX線回折イメージングは, 結晶構造解析だけ でなく多様な非晶質の構造を明らかにできる。これによ り細胞分裂における染色体形成の分子メカニズムが明ら かにできる可能性があるということで注目されている。 さらにピコ秒より短いパルスの特性を生かしたX線構造 解析は，化学反応中の分子構造変化を直接見ることを可 能にする. 得られた化学反応中間体の分子構造をもとに より効果的・効率的な化学反応設計の可能性があり, 太 陽電池や光触媒など光エネルギー変換デバイスの開発か らも期待されている. 生物分子, 固体から取り扱うエネ ルギー密度をさらに大きくすると, 固体の格子構造が崩 れプラズマになっていく，あるいは固体状態でも超高圧 の地上では存在できない極限環境下の状態が生まれてく る。このような大きなエネルギー密度の状態を高エネル ギー密度状態と言う。近年のパワーレーザー技術の進歩 により, 惑星内部でしか存在しないようなこのような超
高圧の極限状態である高エネルギー密度状態が比較的容 易に実験室で実現できる，XFELの高輝度性，あるいは パワー密度は, この高エネルギー密度状態という極限状 態を創り出すことにも貢献できる．XFELはプローブ光 源であるだけでなくポンプ光源として極限状態を創り出 す新たな道具である。

以上のようにXFEL応用は，生命科学から宇宙物理学 まで幅広い分野から期待されおり，米国，日本に続い て2017年には欧州XFELが発振に成功するとともに世界 各地でXFELの建設計画が進められている。このような 状況の中で本特集号では，XFELがもつ高輝度性，短パ ルス性 ( 10 fs $)$, 高分解能性 $(\sim \mathrm{nm})$ といった性質を利 用した応用に関する研究を紹介している。

まずXFELの短波長性，短パルス性を活かした極限的 なプローブ光源の応用例を示した。電子デバイス開発に つながる超高速反強磁性秩序変化や光化学反応などの超 高速現象をプローブする研究に関するものを紹介してい る。また人工光合成や人工触媒をデザインする上で必要 不可欠な水分解反応機構の解明についても解説いただい ている。 さらに可視パワーレーザーで実現できるように なった数 100 万気圧以上の超高圧下での極限的物質構造 変化などを紹介している。またレーザー超高強度場によ り励起された真空双極子をXFELでプローブするとい量 子真空物理学へのチャレンジに関しても解説している.

一方，XFELの短波長性，短パルス性に加え高輝度性を 活用しXFELをポンプ光として活用することで，原子 . 分子を制御し新たなデバイスへの可能性につながる研究 成果に関しても解説いただいている.

ここでは紙面の都合で全てを網羅することができな かったＸXFELの可能性の広さや世界のXFEL建設計画を 考えると，今後，学際的・俯瞰的な視点と共に目標を明 確に設定した戦略的な取り組みが，より一層不可欠とな るものと考えられる. 